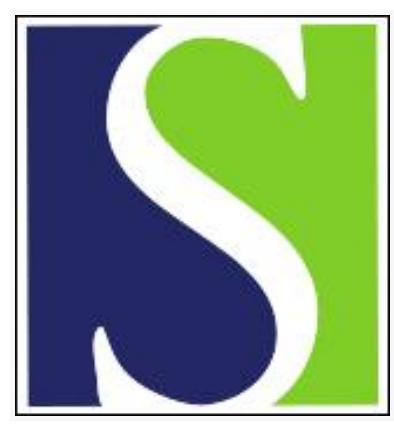

Scand J Work Environ Health 1990;16(3):208-214

https://doi.org/10.5271/sjweh.1802

Issue date: 01 Jun 1990

An in vitro method for predicting sensitizing properties of inhaled chemicals.

by Wass U, Belin L

Affiliation: Department of Medicine I, Sahlgrenska Hospital, Goteborg, Sweden.

This article in PubMed: www.ncbi.nlm.nih.gov/pubmed/2116661

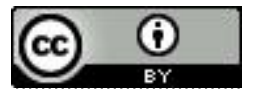




\title{
An in vitro method for predicting sensitizing properties of inhaled chemicals
}

\author{
by Urban Wass, DrMedSc, Lars Belin, MD ${ }^{1}$
}

\begin{abstract}
WASS U, BELIN L. An in vitro method for predicting sensitizing properties of inhaled chemicals. Scand $J$ Work Environ Health 1990;16:208-14. A method for monitoring chemical reactivity in aqueous solutions, at neutral $\mathrm{pH}$ and $37^{\circ} \mathrm{C}$, was developed. The chemical was allowed to react with a lysine-containing peptide, and the reaction was monitored with high-performance liquid chromatography. Simple acids, bases, and solvents did not react with the peptide, whereas isocyanates, anhydrides, and chloramine- $T$, substances well known for their sensitizing and asthma inducing properties, did. Thus a positive test strongly suggested that the chemical had the potential to act as a hapten and cause sensitization when inhaled. Prepolymers of diphenylmethane diisocyanate were considerably more reactive than prepolymers of toluene diisocyanate or hexamethylene diisocyanate. Isocyanates blocked with caprolactam, butanone oxime, malonic acid diethylester, or isononyl phenol showed no reactivity. This result suggested a significantly reduced risk of respiratory reactions when such blocked isocyanates are handled at room temperature. One blocked isocyanate showed, however, considerable reactivity.
\end{abstract}

Key terms: allergy, asthma, blocked isocyanates, hapten, respiratory tract sensitization.

It is known that some chemicals with a low molecular weight can induce respiratory symptoms similar to an allergic type I reaction. The clinical features indicate that the symptoms may, at least in some cases, be caused by a true type I hypersensitivity reaction. Associations between allergy-like respiratory symptoms and specific immunoglobulin (Ig) $\mathrm{E}$ antibodies have been demonstrated for isocyanates $(1-19)$, reactive textile dyes $(20-24)$, acid anhydrides $(25-29)$, platinum group metal salts $(30,31)$, and the disinfectant chloramine- $\mathrm{T}$ ( $\mathrm{p}$-toluenesulfonamide, $\mathrm{n}$-chloro, sodium salt, trihydrate; CAS 127-65-1) (32, 33). Furthermore, traces of the sterilizing gas ethylene oxide in hemodialysis filters have been shown to sensitize patients undergoing treatment (34-48).

A substance that is able to bind to a protein or other macromolecule in vivo and act as a hapten can also be anticipated to cause disturbances in the respiratory tract through mechanisms other than immunologic ones. Such substances may, for instance, interfere with receptor proteins or enzymes. This phenomenon has been suggested, on the basis of in vitro studies, for the reactive isocyanates (49). Furthermore, a recent in vitro study suggested that the pharmacological effect of toluene diisocyanate (TDI) may result from an autonomic imbalance between cholinergic and B-adrenergic neural control (50). The known respiratory effects of isocyanates have been reviewed by Musk et al (51).

The hypothesis behind this present work was that there ought to be a correlation between the ability of

1 The Asthma and Allergy Research Centre, Department of Medicine I, Sahlgrenska Hospital, Göteborg, Sweden.

Reprint requests to: Dr U Wass, The Asthma and Allergy Research Centre, Department of Medicine 1, Sahlgrenska Hospital, S-413 45 Göteborg, Sweden. a substance to react with proteins and its potential to induce respiratory tract dysfunction. Furthermore, we assumed that a well-chosen peptide could replace the protein in an in vitro assay. The use of a peptide was considered advantageous, as we anticipated technical difficulties in demonstrating, and quantifying accurately, the reaction between a chemical with a low molecular weight and a protein. Thus the objective of this work was to develop a method of monitoring the reaction between a chemical and a suitable peptide.

The choice of the amino acid sequence of the peptide was based on previously published data. Lysine was our first choice, as in vitro studies had shown that, when added to proteins, isocyanates and anhydrides react with this amino acid $(52,53)$. Lysine has an epsilon amino group which can take part in the reaction and has also been shown to be the most likely residue for the covalent binding of chloramine-T to a protein, although tyrosine, methionine, cysteine, and histidine were also modified by the substance (54). Furthermore, lysine has been shown to be involved in the reaction between proteins and ethylene oxide (55).

The second amino acid chosen was tyrosine. This amino acid absorbs ultraviolet light and can thus be detected easily in high-performance liquid chromatography (HPLC). Tyrosine has also been shown to be involved in the reaction between chloramine- $T$ and proteins (54). On the basis of these considerations, three peptides containing lysine-tyrosine were investigated.

After a suitable test procedure had been established, we estimated the reactivity of various chemicals and industrially used isocyanate products to see if the reactivity was related to known respiratory effects of the substances. 


\section{Material and methods}

\section{Reagents}

The peptides L-lysyl-L-tyrosyl-L-lysine $\cdot 2$ formiate (LTL) (molecular weight 530), L-lysyl-L-tyrosyl-Lglutamic acid (LTG) and L-lysyl-L-tyrosine - acetate (LT) were purchased from Bachem Feinchemicalien AG, Bubendorf, Switzerland. Tetrahydrofuran (for chromatography) and molecular sieve $3 \AA$ (2-mm beads) were obtained from E Merck, Darmstadt, Federal Republic of Germany. Acetonitrile $\left(\mathrm{CH}_{3} \mathrm{CN}\right.$, HPLC grade), 1-octane sulfonic acid sodium salt (HPLC grade), and 1-pentane sulfonic acid sodium salt (HPLC grade) were obtained from Fisons, Loughborough, England. The other reagents used were of analytical grade. Test-tubes (labeled KIMAX, USA, length $10 \mathrm{~cm}$, diameter $13 \mathrm{~mm}$ ) with screw caps and teflon-faced rubber liners were purchased from Kebo Lab, Stockholm, Sweden.

Industrially used isocyanates were collected from a Swedish polyurethane factory or were obtained from Bayer AG, Leverkusen, Federal Republic of Germany. Three reactive textile dyes (from the "Remazol" series produced by the Hoechst company) were collected from a Swedish dye house. These dyes were Remazol Black B (color index reactive black 5), Remazol Brilliant Blue R Spec (color index reactive blue 19) and Remazol Brilliant Yellow 4GL (color index reactive yellow 160).

Acetonitrile and tetrahydrofuran, used to dilute the test samples, were dried for $24 \mathrm{~h}$ with $10 \mathrm{~g}$ of molecular sieve per $100 \mathrm{ml}$.

\section{High-performance liquid chromatography}

For reversed phase HPLC, Nova-Pak C18 Radial$\mathrm{Pak}^{\mathrm{TM}}$ cartridges $(4 \mu \mathrm{m}$ particles, column length $10 \mathrm{~cm}$, inner diameter $8 \mathrm{~mm}$ ) and $\mu$-Bondapak $\mathrm{C} 18$ Guard-Pak ${ }^{\mathrm{TM}}$ precolumn inserts were obtained from Waters Associates, Inc, Milford, Massachusetts, United States.

The mobile phase in the HPLC consisted of $58 \%$ methanol and $42 \%$ aqueous buffer (volume $\%$ ). The buffer was prepared by dissolving $5 \mathrm{~g}$ of 1 -octane sulfonic acid sodium salt, $1.5 \mathrm{~g}$ of 1-pentane sulfonic acid sodium salt, and $1 \mathrm{ml}$ of triethylamine per liter of water. Before the buffer was used, its $\mathrm{pH}$ was adjusted to 3.0 by the addition of 10 volume $\%$ phosphoric acid.

The samples were chromatographed at a flow rate of $2 \mathrm{ml} / \mathrm{min}$ with ultraviolet detection at $280 \mathrm{~nm}$. Ambient temperature and an injected volume of $50 \mu \mathrm{l}$ were used. The reproducibility in HPLC was investigated by 12 consecutive injections of an $0.1 \mu \mathrm{mol} / \mathrm{ml}(53$ $\mu \mathrm{g} / \mathrm{ml}$ ) solution of LTL. Overall variations in the test system were estimated by testing 10 industrially used isocyanate products, repeating the test after $2 \mathrm{~d}$, and studying the performance of duplicate samples according to the method described by Barnett (56).

\section{Pilot experiments}

The reaction between isocyanates and peptides was studied as a model for all reactive chemicals. Various combinations of isocyanate and peptide concentrations were used, and several mobile phases were tested. The reaction between ethylene oxide, at a high concentration, and LTL was also studied.

\section{Test procedure}

LTL was dissolved in an $0.02 \mathrm{~mol} / 1$ sodium phosphate buffer (a mixture of $0.02 \mathrm{~mol} / \mathrm{l}$ sodium dihydrogen phosphate and $0.02 \mathrm{~mol} / 1$ sodium hydrogen phosphate $\mathrm{pH} 7.0$ ) to a final concentration of $0.1 \mu \mathrm{mol} / \mathrm{ml}$. Aliquots of the solution were used the same day or stored frozen at $-20^{\circ} \mathrm{C}$.

The test sample was dissolved in water to a final concentration of $4.0 \mu \mathrm{mol} / \mathrm{ml}$. Samples that were not soluble, or stable, in water were dissolved in acetonitrile instead.

To test a sample, $50 \mu \mathrm{l}$ of the sample solution $(4.0 \mu \mathrm{mol} / \mathrm{ml})$ was added to $500 \mu \mathrm{l}$ of the LTL solution $(0.1 \mu \mathrm{mol} / \mathrm{ml})$ in a test-tube at ambient temperature. The capped test-tube was then immediately placed in a $37^{\circ} \mathrm{C}$ water bath for $10 \mathrm{~min}$ and, before injection, in a $20^{\circ} \mathrm{C}$ (ambient temperature) water bath for $1 \mathrm{~min}$.

During the HPLC, $50 \mu \mathrm{l}$ of the mixture was injected, and the area for the LTL peak was measured. This peak area was compared with the area for the unreacted LTL peak, ie, the peak obtained when $50 \mu \mathrm{l}$ of water (or acetonitrile) was mixed with $500 \mu$ l of the LTL solution. The percentage of LTL that had reacted with the test sample was calculated, divided by 10 , and rounded off to the nearest integer. The resulting figure was named the "peptide reactivity index," and it ranged from 0 , when no detectable reaction could be noted, to 10 , when all LTL had reacted.

\section{Industrially used isocyanates}

Products based on hexamethylene diisocyanate (HDI), diphenylmethane diisocyanate (MDI), toluene diisocyanate (TDI), isophoron diisocyanate (IPDI), and naphthylene diisocyanate (NDI) were tested.

As the molecular weight of many industrially used isocyanates was not known (or could not be defined) and as mixtures were often used, a slight modification of the procedure that has already been presented was adopted for such samples. A hypothetical molecular weight of 500 was assumed, ie, $4 \mu \mathrm{mol} / \mathrm{ml}$ corresponded to $2 \mathrm{mg} / \mathrm{ml}$.

Furthermore, some isocyanate products were difficult to dissolve directly in acetonitrile. These products were dissolved in tetrahydrofuran $(20 \mathrm{mg} / \mathrm{ml})$ as a first step and then diluted with acetonitrile to $2 \mathrm{mg} / \mathrm{ml}$.

Thus $50 \mu \mathrm{l}$ of the isocyanate solution $(2 \mathrm{mg} / \mathrm{ml}$ in acetonitrile) was added to $500 \mathrm{pl}$ of the LTL solution $(0.1 \mu \mathrm{mol} / \mathrm{ml})$ in a test-tube and treated as has already been described. 


\section{Results}

\section{Pilot experiments}

Acetonitrile could be used as a solvent as it did not affect the peptides. All three peptides (LTL, LTG and LT) had the ability to react with the isocyanates MDI, TDI (a mixture of the 2,4- and 2,6-isomers) and HDI. LTL was, however, found to be the peptide with the longest retention time. Generally, LTL was the peptide that showed the best separation from the other components in the chromatograms. For this reason, LTL was chosen for the experiments that followed. The detection limit of LTL was approximately 0.001 $\mu \mathrm{mol} / \mathrm{ml}$.

The relative standard deviation [coefficient of variation (CV)] of the HPLC, investigated by 12 consecutive injections of an $0.1 \mu \mathrm{mol} / \mathrm{ml}(53 \mu \mathrm{g} / \mathrm{ml})$ solution of LTL, was $2 \%$. The standard deviation for the complete test procedure, estimated from tests of isocyanate products on two different occasions and the determination of the differences between duplicate samples, corresponded to approximately $4 \%$ of the original

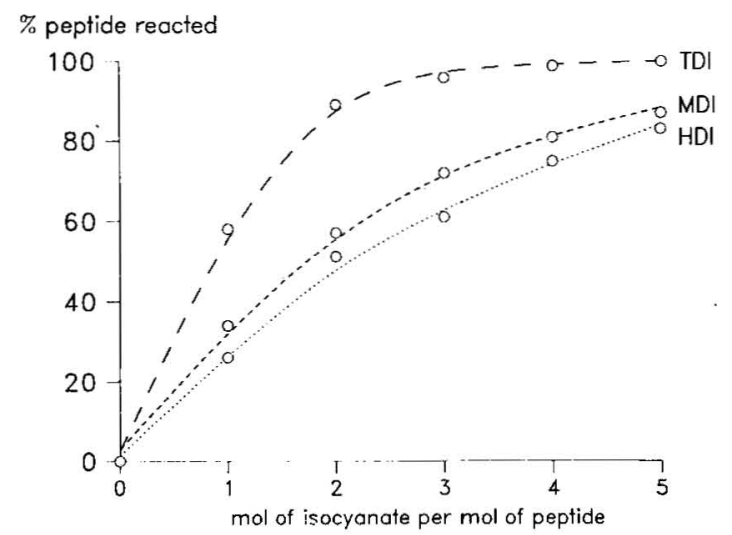

Figure 1. The percentage of the L-lysyl-L-tyrosyl-L-lysine (LTL) peptide that reacted for various isocyanate:LTL molar ratios. Diphenylmethane diisocyanate (MDI), toluene diisocyanate (TDI), and hexamethylene disocyanate (HDI) were allowed to react with LTL $(0.1 \mu \mathrm{mol} / \mathrm{ml})$ at $37^{\circ} \mathrm{C}$ for $10 \mathrm{~min}$.
LTL peak area. The retention time for $L T L$ decreased linearly as the column temperature increased. The retention time at $50^{\circ} \mathrm{C}$ was approximately half that obtained at $20^{\circ} \mathrm{C}$. Ambient temperature was chosen, but the experiment showed that temperature was a variable that could have been changed if the LTL peak had not been fully resolved in the chromatogram.

MDI, TDI, and HDI were allowed to react with LTL $(0.1 \mu \mathrm{mol} / \mathrm{ml})$ at various molar ratios (figure 1$)$. The percentage of the peptide that reacted increased as the isocyanate:peptide ratio increased, and the differences between the three isocyanates were noted. The potential to react with LTL was highest for TDI, followed by MDI and HDI in that order. From the results illustrated in figure 1, a molar ratio of 4 between the test sample and the LTL peptide was chosen. At this ratio, TDI reached the $100 \%$ level of reacted peptide. Furthermore, differences between the individual isocyanates were clearly noted, whereas a considerably higher ratio would eliminate this difference. A typical chromatogram from a test of HDI is shown in figure 2. As can be seen, HDI itself did not produce peaks that interfered with LTL. It will also be seen that only about $30 \%$ of the original LTL peak remained after the reaction with HDI, which corresponded to a peptide reactivity index of 7 . The reaction products of HDI and LTL were probably represented by additional peaks with retention times between approximately 2 and $4 \mathrm{~min}$ (figure 2, chromatogram D).

No detectable reaction was noted between ethylene oxide and LTL at a molar ratio of 4.0. A clear decrease in the LTL peak area was, however, observed when the ratio was increased to 450 and the reaction was monitored for $3 \mathrm{~h}$. Under these conditions, an amount of LTL corresponding to approximately $15 \%$ of the original amount was reacted per hour.

\section{Chemicals}

Several well-defined chemicals were allowed to react with LTL for $10 \mathrm{~min}$ at $37^{\circ} \mathrm{C}$ and at a molar ratio of 4 . The same procedure was also used for three reactive textile dyes collected directly from a dye house.
A) Blank
B) $H D I$
C) LTL
D) $H D I+L T L$

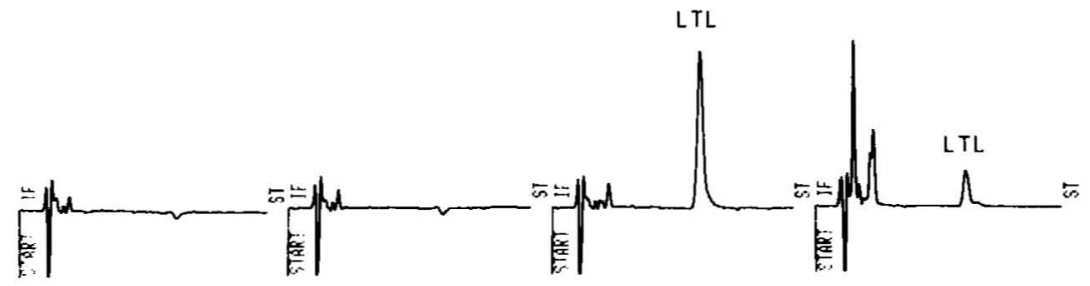

Figure 2. Chromatograms from a test of hexamethylene diisocyanate (HDI) according to a normal test procedure [0.1 $\mu \mathrm{mol} / \mathrm{l}$ L-lysyl-L-tyrosyl-L-lysine (LTL), HDI:LTL molar ratio 4]. The retention time for LTL was 8.5 min.[A) blank: acetonitrile added to buffer, B) HDI: HDI in acetonitrile added to buffer), C) LTL: acetonitrile added to buffer with LTL, D) HDI + LTL: HDI in acetonitrile added to buffer with LTL] 
Table 1. Results obtained for well-defined chemicals of analytical grade and for three reactive textile dyes collected directly from a dye house. In the test, $50 \mu$ l of the sample solution $(4.0 \mu \mathrm{mol} / \mathrm{ml})$ was added to $500 \mu \mathrm{l}$ of the L-lysyl-L-tyrosyl-L lysine (LTL) solution $(0.1 \mu \mathrm{mol} / \mathrm{ml})$, corresponding to a molar ratio of 4 between the sample and the LTL peptide. The solvent used for the tested chemical is indicated in the table.

\begin{tabular}{|c|c|c|}
\hline Chemical substance & Solvent & $\begin{array}{l}\text { Peptide } \\
\text { reactivity } \\
\text { index }\end{array}$ \\
\hline \multicolumn{3}{|l|}{ Acids/bases } \\
\hline $\begin{array}{l}\text { Ammonium hydroxide }\left(\mathrm{NH}_{3} \mathrm{aq}\right) \\
\text { Formic acid } \\
\text { Hydrochloric acid } \\
\text { Perchloric acid }\end{array}$ & $\begin{array}{l}\text { Water } \\
\text { Water } \\
\text { Water } \\
\text { Water }\end{array}$ & $\begin{array}{l}0 \\
0 \\
0 \\
0\end{array}$ \\
\hline \multicolumn{3}{|l|}{ Amines } \\
\hline $\begin{array}{l}\text { 3-Dimethylamino-1-propylamine } \\
\text { Ethanolamine } \\
\text { Ethylenediamine } \\
\text { Triethylamine }\end{array}$ & $\begin{array}{l}\text { Water } \\
\text { Water } \\
\text { Water } \\
\text { Water }\end{array}$ & $\begin{array}{l}0 \\
0 \\
0 \\
0\end{array}$ \\
\hline \multicolumn{3}{|l|}{ Anhydrides } \\
\hline $\begin{array}{l}\text { Hexahydrophthalic anhydride } \\
\text { Maleic anhydride } \\
\text { Phthalic anhydride } \\
\text { Tetrachlorophthalic anhydride } \\
\text { Trimellitic anhydride }\end{array}$ & $\begin{array}{l}\text { Acetonitrile } \\
\text { Acetonitrile } \\
\text { Acetonitrile } \\
\text { Acetonitrile } \\
\text { Acetonitrile }\end{array}$ & $\begin{array}{r}9 \\
10 \\
10 \\
7 \\
10\end{array}$ \\
\hline \multicolumn{3}{|l|}{ Dinitrobenzenes } \\
\hline $\begin{array}{l}\text { 1.Chloro-2,4-dinitrobenzene } \\
\text { 1-Fluoro-2,4-dinitrobenzene }\end{array}$ & $\begin{array}{l}\text { Acetonitrile } \\
\text { Acetonitrile }\end{array}$ & $\begin{array}{l}0 \\
0\end{array}$ \\
\hline \multicolumn{3}{|l|}{ Isocyanates } \\
\hline $\begin{array}{l}\text { Diphenylmethane disocyanate (MDI) } \\
\text { Isophoron diisocyanate } \\
\text { Hexamethylene diisocyanate (HDI) } \\
\text { Phenyl isocyanate } \\
\text { Toluene disocyanate (TDI) } \\
\text { Toluene-4-monoisocyanate }\end{array}$ & $\begin{array}{l}\text { Acetonitrile } \\
\text { Acetonitrile } \\
\text { Acetonitrile } \\
\text { Acetonitrile } \\
\text { Acetonitrile } \\
\text { Acetonitrile }\end{array}$ & $\begin{array}{r}8 \\
5 \\
7 \\
7 \\
10 \\
9\end{array}$ \\
\hline \multicolumn{3}{|l|}{ Miscellaneous } \\
\hline $\begin{array}{l}\text { Ammonium hexachloroplatinate (IV) } \\
\text { Chloramine-T } \\
\text { Ethyl methacrylate } \\
\text { Ethylene oxide } \\
\text { Formaldehyde } \\
\text { Hydrogen peroxide } \\
\text { Isobutyl chloroformate } \\
\text { 2-Mercaptoethanol } \\
\text { 2-Methylbenzoylchloride } \\
\text { N,N'-Methylenediacrylamide } \\
\text { Phenacyl bromide } \\
\text { Phenol } \\
\text { Sodium persulfate } \\
\text { Sodium sulfite } \\
\text { Toluene-4-sulphonamide }\end{array}$ & $\begin{array}{l}\text { Water } \\
\text { Water } \\
\text { Acetonitrile } \\
\text { Water } \\
\text { Water } \\
\text { Water } \\
\text { Acetonitrile } \\
\text { Water } \\
\text { Acetonitrile } \\
\text { Water } \\
\text { Acetonitrile } \\
\text { Water } \\
\text { Water } \\
\text { Water } \\
\text { Acetonitrile }\end{array}$ & $\begin{array}{l}0 \\
5 \\
0 \\
0 \\
0 \\
0 \\
7 \\
0 \\
0 \\
0 \\
0 \\
0 \\
0 \\
0 \\
0\end{array}$ \\
\hline \multicolumn{3}{|l|}{ Organic solvents } \\
\hline $\begin{array}{l}\text { Acetone } \\
\text { Butanol (Butan-1-ol) } \\
\text { n-Butyl acetate } \\
\text { Dichloromethane } \\
\text { Diisopropyl ether } \\
\text { Propanol (Propan-2-ol) }\end{array}$ & $\begin{array}{l}\text { Water } \\
\text { Acetonitrile } \\
\text { Acetonitrile } \\
\text { Acetonitrile } \\
\text { Acetonitrile } \\
\text { Water }\end{array}$ & $\begin{array}{l}0 \\
0 \\
0 \\
0 \\
0 \\
0\end{array}$ \\
\hline \multicolumn{3}{|l|}{ Reactive textile dyes } \\
\hline $\begin{array}{l}\text { Remazol Black B } \\
\text { Rernazol Brilliant Blue R Spec } \\
\text { Remazol Brilliant Yellow 4GL }\end{array}$ & $\begin{array}{l}\text { Water } \\
\text { Water } \\
\text { Water }\end{array}$ & $\begin{array}{l}0 \\
0 \\
0\end{array}$ \\
\hline
\end{tabular}

a See Test Procedure in the Material and Methods section for an explanation of the index.

The results, expressed as the peptide reactivity index, are shown in table 1 .

The industrially used isocyanate products were tested at a concentration of $2 \mathrm{mg} / \mathrm{ml}$, ie, a hypothetical molecular weight of 500 was assumed. The results, grouped according to the type of isocyanate product, are shown in table 2 . The blocked isocyanates were dissolved in tetrahydrofuran $(20 \mathrm{mg} / \mathrm{ml})$ as a first step and then diluted with acetonitrile to $2 \mathrm{mg} / \mathrm{ml}$. Monomeric isocyanates had been found previously to elicit the same peptide reactivity index regardless of whether
Table 2. Results obtained for industrially used isocyanate products. In the test, $50 \mu \mathrm{l}$ of the isocyanate solution $(2 \mathrm{mg} / \mathrm{m}$. in acetonitrile) was added to $500 \mu l$ of the L-Iysyl-L-tyrosyl-L Iysine (LTL) solution $(0.1 \mu \mathrm{mol} / \mathrm{ml})$. The isocyanates are grouped according to the type of product. $(\mathrm{N}=$ the number of isocyanate products tested within each group, $\mathrm{HDI}=$ hexamethylene diisocyanate, $I P D I=$ isophoron diisocyanate, MDI = diphenyImethane diisocyanate, $\mathrm{NDI}$ = naphthylene diisocyanate, TDI = toluene diisocyanate)

\begin{tabular}{|c|c|c|c|}
\hline $\begin{array}{l}\text { Type of } \\
\text { isocyanate }\end{array}$ & $\begin{array}{l}\text { Peptide } \\
\text { reactivity } \\
\text { index }\end{array}$ & $\mathrm{N}$ & Comment \\
\hline \multicolumn{4}{|c|}{ Mainly monomers } \\
\hline $\begin{array}{l}\text { MDI } \\
\text { TDI } \\
\text { NDI } \\
\text { IPDI }\end{array}$ & $\begin{array}{c}7-10 \\
10 \\
9 \\
9\end{array}$ & $\begin{array}{l}7 \\
1 \\
1 \\
1\end{array}$ & $80 \% 2,4-$ TDI and $20 \% 2,6$-TDI \\
\hline \multicolumn{4}{|l|}{ Prepolymers } \\
\hline $\begin{array}{l}\text { HDI } \\
\text { TDI } \\
\text { MDI }\end{array}$ & $\begin{array}{l}1-3 \\
1-3 \\
5-10\end{array}$ & $\begin{array}{l}5 \\
4 \\
4\end{array}$ & $\dot{.}$ \\
\hline \multicolumn{4}{|c|}{ Blocked isocyanates } \\
\hline $\begin{array}{l}\text { HDI } \\
\text { IPDI } \\
\text { MDI } \\
\text { TDI } \\
\text { TDI } \\
\text { TDI } \\
\text { TDI }\end{array}$ & $\begin{array}{l}0 \\
0 \\
0 \\
0 \\
0 \\
0 \\
3\end{array}$ & $\begin{array}{l}1 \\
1 \\
1 \\
2 \\
1 \\
1 \\
1\end{array}$ & $\begin{array}{l}\text { Blocked with butanone oxime } \\
\text { Blocked with butanone oxime } \\
\text { Blocked with malonic acid ester } \\
\text { Blocked with caprolactam } \\
\text { Blocked with isononyl phenol } \\
\text { Blocked with aliphatic alcohol } \\
\text { Blocked with phenol }\end{array}$ \\
\hline \multicolumn{4}{|c|}{$\begin{array}{l}\text { Hardeners for } \\
\text { polyurethane } \\
\text { lacquers }\end{array}$} \\
\hline HDI & $2-3$ & 2 & . \\
\hline
\end{tabular}

a See Test Procedure in the Material and Methods section for an explanation of the index.

they were directly dissolved in acetonitrile or tetrahydrofuran as a first step.

\section{Discussion}

Chemical reactivity is a relative concept. Industrially used chemicals may be reactive in organic solvents, at elevated pressures and temperatures, at extreme $\mathrm{pH}$ values, in the presence of catalysts and initiating substances, etc. The reactivity we wanted to estimate was that relevant to biological conditions, ie, aqueous solutions, neutral $\mathrm{pH}$, and a temperature of $37^{\circ} \mathrm{C}$.

Several reactive industrial chemicals have been found to exert sensitizing and toxic effects, presumably by interaction with mucosal surface proteins. An in vitro test system simulating this in vivo protein interaction was designed. We wanted to work with diluted solutions, since the concentration of inhaled chemicals is generally low. However, the analytical difficulties and the influence of trace impurities in solvents and buffers increase when low concentrations are to be analyzed. We found an LTL concentration of $0.1 \mu \mathrm{mol} / \mathrm{ml}$ to be a suitable compromise.

For statistical reasons, the decrease in the LTL peak area for a single injection of a sample had to be at least approximately $5 \%$ to be considered significant on the $99 \%$ confidence level (normal distribution, one-tailed test). We wanted to report the results on a scale on which each increment represented a significant difference, and a scale from 0 to 10 was chosen. 
Table 1 clearly shows that LTL was not affected by simple acids, bases, and solvents. Isocyanates, anhydrides, and chloramine- $T$, on the other hand, elicited peptide reactivity indexes in the range of 5 to 10 .

It should be noted that not all substances known to sensitize the respiratory tract could be shown to react with the LTL peptide at a molar ratio of 4 . For instance, the three reactive dyes tested did not. In this case the explanation may be that such dyes act as haptens without any covalent binding to a protein at neutral $\mathrm{pH}$. Reactive dyes are normally activated by alkali before they become reactive and are able to bind covalently to textile fibers. Several reactive dyes have been shown to bind to human serum albumin and human IgG through adsorption (57-59), and we have previously suggested that covalent bonds may not always be necessary for the in vivo formation of dyeprotein conjugates (24). Thus reactivity does not seem to be a prerequisite for hapten sensitization.

The reactivity of ethylene oxide seems to be too low to induce hypersensitivity reactions when inhaled. We found no specific IgE antibodies among 20 workers who worked in a plant producing ethylene oxide and were suspected of having work-related respiratory symptoms (Wass \& Belin, unpublished data). However, hypersensitivity reactions to ethylene oxide have occurred among dialysis patients when the gas has had direct access to the blood in the dialysis filter. These circumstances might be reflected in the peptide test, in which no reaction was noted at a low ethylene oxide concentration (molar ratio $4,10 \mathrm{~min}$ ), but the substance revealed its reactivity clearly when the molar ratio was increased to 450 and the reaction was monitored for several hours.

One major application of this study concerns isocyanates, a group of reactive chemicals which has achieved ever-increasing technical importance in the last couple of decades. They are the starting materials for polymers called polyurethanes. Polyurethanes are used as flexible foam, rigid foam, electrical insulation material, lacquers, elastomers, glues, etc. The health hazards associated with isocyanates have been known for many years, and the use of these substances is regulated in Sweden and many other countries.

In spray painting, isocyanate-based coatings are used for automobiles, airplanes, railroad cars, furniture, etc. The necessary spray equipment is easier to produce and handle if a one-component paint is used (all ingredients are premixed in the paint) than if two-component systems (the isocyanate is mixed with the other ingredients during the spray operation) are used. The search for one-component systems that are stable enough to be stored for several months has led to products in which the reactive isocyanate $(\mathrm{NCO})$ groups are blocked at ambient temperatures. Caprolactam, butanone oxime, and malonic acid diethylester have been used as blocking agents for isocyanates (60). Temperatures above $100^{\circ} \mathrm{C}$ are needed to release the blocking of the $\mathrm{NCO}$ groups. Our data (table 2) indicate that isocyanates blocked with these three agents are inactive at $37^{\circ} \mathrm{C}$. This finding suggests a significantly reduced risk of respiratory reactions when such blocked isocyanates are handled at room temperature, compared with prepolymers or monomers of isocyanates. From a theoretical point of view, an enzymatic degradation of blocked isocyanates in vivo to the corresponding free isocyanate (with $\mathrm{NCO}$ groups) may be claimed but, as far as we know, this hypothesis has not been supported by either in vivo or in vitro experiments.

The blocked isocyanate with phenol as the blocking agent, on the other hand, showed considerable reactivity. We tested two different batches of this product with the same result, peptide reactivity index 3; phenol itself did not react with LTL. Isocyanates blocked with phenol represent an old type of product that has been used mainly for wire coatings. It is interesting to note that the only report, as far as we know, of respiratory symptoms in regard to an occupational exposure to blocked isocyanates describes a man who sprayed with an adhesive containing a phenolblocked TDI (61). Isononyl phenol, on the other hand, seemed to be an efficient blocking agent.

We found that prepolymers of MDI were considerably more reactive than prepolymers of TDI or HDI. This difference was obviously due to the high content of monomers in the MDI prepolymer, in which monomer concentrations of up to $45 \%$ may exist.

Isobutyl chloroformate $\left(\mathrm{ClCOOCH}_{2} \mathrm{CH}\left(\mathrm{CH}_{3}\right)_{2}\right.$, CAS 543-27-1), a chemical used in analytical chemistry for the activation of carboxyl groups $(62,63)$, was found to have a peptide reactivity index of 7 . This finding suggests a potential risk of respiratory symptoms if the substance is inhaled. We know of no such reports, but the substance is probably handled mostly by experienced chemists using fume hoods and other protective procedures.

We think that a positive test with the present peptide method strongly suggests that the tested chemical has, when inhaled, the potential to act as a hapten or to cause nonimmunologic disturbances (eg, interference with receptor proteins or enzymes). A negative test, on the other hand, does not exclude this possibility. The test result itself is not enough to judge a substance regarding its health hazards but may provide an important piece of information.

Several of our results could have been anticipated from what was known of the chemical properties of the substances. For instance, as phthalic anhydride was known to be a reactive substance, it was natural to expect that the same would apply to trimellitic anhydride. The peptide method can still be useful for substances with well-known chemical properties, however, because the method makes it possible to quantify the reactivity. Furthermore, the method can be applied to the testing of both complex mixtures and new chemicals with largely unknown properties. 


\section{Acknowledgments}

We wish to express our sincere gratitude to the Swedish Work Environment Fund for its generous financial support and to Dr W Slawyk, Professor W Diller, and Dr M Mann at Bayer AG, Leverkusen, the Federal Republic of Germany, for the gift of various isocyanate samples.

\section{References}

1. Karol $\mathrm{MH}$, Ioset $\mathrm{HH}$, Alarie YC. Tolyl-specific $\mathrm{IgE}$ antibodies in workers with hypersensitivity to toluene diisocyanate. Am Ind Hyg Assoc J 1978;39:454-8.

2. Karol MH, Sandberg T, Riley EJ, Alarie Y. Longitudinal study of tolyl-reactive IgE antibodies in workers hypersensitive to TDI. J Occup Med 1979;21:354-8.

3. Karol MH, Alarie Y. Antigens which detect IgE antibodies in workers sensitive to toluene diisocyanate. Clin Allergy 1980;10:101-9.

4. Butcher BT, O'Neil CE, Reed MA, Salvaggio JE. Radioallergosorbent testing of toluene diisocyanate-reactive individuals using p-tolyl isocyanate antigen. J Allergy Clin Immunol 1980;66:213-6.

5. Zeiss CR, Kanellakes TM, Bellone JD, Levitz D, Pruzansky JJ, Patterson R. Immunoglobulin E-mediated asthma and hypersensitivity pneumonitis with precipitating anti-hapten antibodies due to diphenylmethane diisocyanate (MDI) exposure. J Allergy Clin Immunol 1980;65:346-52.

6. Diller W, Baur X, Fruhmann G. Feldstudie mit spezifischen Radio-Allergo-Sorbens-Testen (RAST) bei isocyanat-exponierten (TDI). Zentralbl Arbeitsmed Arbeitssch Prophyl Ergonomie 1980;30:100-3.

7. Danks JM, Cromwell O, Buckingham JA, NewmanTaylor AJ, Davies RJ. Toluene-diisocyanate-induced asthma: evaluation of antibodies in the serum of affected workers against a tolyl mono-isocyanate protein conjugate. Clin Allergy 1981;11:161-8.

8. Callagher JS, Tse CST, Brooks SM, Bernstein IL. Diverse profiles of immunoreactivity in Toluene Diisocyanate (TDI) Asthma. J Occup Med 1981;23:610—6.

9. Game CJA. Australian TDI workers sera assayed for IgE against a p-tolyl-isocyanate-human serum albumin conjugate. Am Ind Hyg Assoc J 1982;43:759-63.

10. Dewair MA, Baur X. Studies on antigens useful for detection of $\operatorname{lgE}$ antibodies in isocyanate-sensitized workers. J Clin Chem Clin Biochem 1982;20:337-40.

11. Malo J-L, Ouimet G, Cartier A, Levitz D, Zeiss CR. Combined alveolitis and asthma due to hexamethylene diisocyanate (HDI), with demonstration of crossed respiratory and immunologic reactivities to diphenylmethane diisocyanate (MDI). J Allergy Clin Immunol 1983;72:413-9.

12. Butcher BT, O'Neil CE, Reed MA, Salvaggio JE. Radioallergosorbent testing with p-tolyl monoisocyanate in toluene diisocyanate workers. Clin Allergy 1983; $13: 31-4$

13. Baur X. Immunologic cross-reactivity between different albumin-bound isocyanates. J Allergy Clin Immunol 1983;71:197-205.

14. Baur X, Dewair M, Fruhmann G. Detection of immunologically sensitized isocyanate workers by RAST and intracutaneous skin test. J Allergy Clin Immunol 1984; 73:610-8.

15. Pezzini A, Riviera A, Paggiaro $P$, et al. Specific IgE antibodies in twenty-eight workers with diisocyanateinduced bronchial asthma. Clin Allergy 1984;14:45361.

16. Tse KS, Johnson A, Chan H, Chan-Yeung M. A study of serum antibody activity in workers with occupational exposure to diphenylmethane diisocyanate. Allergy 1985; 40:314-20.

17. Grunewalder E, Karol MH. Nitrocellulose-based RAST to detect IgE antibodies in workers hypersensitive to diphenylmethane-4,4'-diisocyanate. Allergy 1986;41: $203-9$.

18. Keskinen $\mathbf{H}$, Tupasela $\mathrm{O}$, Tiikkainen U, Nordman $\mathbf{H}$. Experiences of specific IgE in asthma due to diisocyanates. Clin Allergy 1988;18:597-604.

19. Wass U, Belin L. Immunologic specificity of isocyanateinduced IgE antibodies in serum from 10 sensitized workers. J Allergy Clin Immunol 1989;83:126-35.

20. Alanko K, Keskinen H, Björksten F, Ojanen S. Immediate-type hypersensitivity to reactive dyes. Clin Allergy 1978;8:25-31.

21. Luczynska CM, Topping MD. Specific IgE antibodies to reactive dye-albumin conjugates. J Immunol Methods 1986;95:177-86.

22. Hagmar L, Welinder H, Dahlquist I. Immunoglobulin $\mathrm{E}$ antibodies against a reactive dye - a case report. Scand J Work Environ Health 1986;12:221-2.

23. Docker A, Wattie JM, Topping MD, et al. Clinical and immunological investigations of respiratory disease in workers using reactive dyes. $\mathrm{Br} \mathrm{J}$ Ind Med 1987;44: 534-41.

24. Wass U, Nilsson R, Nordlinder R, Belin L. An optimized assay of specific IgE antibodies to reactive dyes and studies of immunologic responses in exposed workers. J Allergy Clin Immunol (in press).

25. Maccia CA, Bernstein IL, Emmet EA, Brooks SM. In vitro demonstration of specific $\lg E$ in phthalic anhydride hypersensitivity. Am Rev Respir Dis 1976;113:701-4.

26. Howe W, Venables KM, Topping MD, et al. Tetrachlorophthalic anhydride asthma: evidence for specific IgE antibody. J Allergy Clin Immunol 1983;71:5-11.

27. Zeiss CR, Levitz D, Chacon R, Wolkousky P, Pattersson R, Pruzansky JJ. Quantitation and new antigenic determinant (NAD) specificity in antibodies induced by inhalation of trimellitic anhydride in man. Int Arch Allergy Appl Immunol 1980;61:380-8.

28. Bernstein DI, Gallagher JS, D'Souza L, Bernstein IL. Heterogeneity of specific-IgE responses in workers sensitized to acid anhydride compounds. J Allergy Clin Immunol 1984;74:794-801.

29. Moller DR, Gallagher JS, Bernstein DI, Wilcox TG, Burroughs $\mathrm{HE}$, Bernstein IL. Detection of IgE-mediated respiratory sensitization in workers exposed to hexahydrophthalic anhydride. J Allergy Clin Immunol 1985; 75:663-72.

30. Murdoch RD, Pepys J, Hughes EG. IgE antibody responses to platinum group metals: a large scale refinery survey. Br J Ind Med 1986;43:37-43.

31. Murdoch RD, Pepys J. Platinum group metal sensitivity: reactivity to platinum group metal salts in platinum halide salt-sensitive workers. Ann Allergy 1987;59: 464-9.

32. Kramps JA, van Toorenenbergen AW, Vooren PH, Dijkman JH. Occupational asthma due to inhalation of chloramine-T: II. demonstration of specific IgE antibodies. Int Arch Allergy Appl Immun 1981;64:428-38.

33. Wass U, Belin L, Eriksson NE. Immunological specificity of chloramine-T induced IgE antibodies in serum from a sensitized worker. Clin Exp Allergy 1989;19: $463-71$.

34. Dolovich J, Bell B. Allergy to a product(s) of ethylene oxide gas: demonstration of IgE and IgG antibodies and hapten specificity. J Allergy Clin Immunol 1978;62: $30-2$.

35. Dolovich J, Marshall CP, Smith EKM, et al. Allergy to ethylene oxide in chronic hemodialysis patients. Artif Organs 1984;8:334-337.

36. Grammer LC, Roberts M, Nicholls AJ, Platts MM, Patterson R. lgE against ethylene oxide-altered human 
serum albumin in patients who have had acute dialysis reactions. J Allergy Clin Immunol 1984;74:544-6.

37. Marshall C, Shimizu A, Smith EKM, Dolovich J. Ethylene oxide allergy in a dialysis center: prevalence in hemodialysis and peritoneal dialysis populations. Clin Nephrol 1984;21:346-9.

38. Caruana RJ, Hamilton RW, Pearson FC. Dialyzer hypersensivity syndrome: possible role of allergy to ethylene oxide: report of 4 cases and review of the literature. Am J Nephrol 1985;5:271-4.

39. Grammer LC, Paterson BF, Roxe D, et al. IgE against ethylene oxide-altered human serum albumin in patients with anaphylactic reactions to dialysis. J Allergy Clin Immunol 1985;76:511-4.

40. Marshall CP, Pearson FC, Sagona MA, et al. Reactions during hemodialysis caused by allergy to ethylene oxide gas sterilization. J Allergy Clin Immunol 1985;75: 563-7.

41. Meynadier JM, Guillot B, Issautier R, Flavier JL, Meynadier $\mathbf{J}$. Allergie immédiate à l'oxyde d'éthylène chez un malade hémodialysé. Presse Med 1985;14:1245.

42. Rumpf KW, Seubert S, Seubert A, et al. Association of ethylene-oxide-induced $\mathrm{IgE}$ antibodies with symptoms in dialysis patients. Lancet $1985 ; 2: 1385-7$.

43. Rumpf KW, Seubert S, Seubert A, et al. Hypersensitivitätsphänomene bei Dialysepatienten. Dtsch Med Wochenschr 1985;110:1641-5.

44. Leitman SF, Boltansky H, Alter HJ, Pearson FC, Kaliner MA. Allergic reactions in healthy plateletpheresis donors caused by sensitization by ethylene oxide gas. N Engl J Med 1986;315:1192-6.

45. Muylle L, Baeten M, Avonts G, Peetermans ME. Anaphylactoid reaction in platelet-pheresis donor with IgE antibodies to ethylene oxide. Lancet 1986;2:1225.

46. Patterson R, Lerner C, Roberts M, Moel D, Grammer LC. Ethylene oxide (ETO) as a possible cause of an allergic reaction during peritoneal dialysis and immunologic detection of ETO from dialysis tubing. Am J Kidney Dis 1986;8:64-6.

47. Röckel A, Wahn U, Hertel J, Fiegel P. Ethylene oxide hypersensitivity in dialysis patients. Lancet 1986;2: $382-3$.

48. Wass U, Belin L, Delin K. Longitudinal study of specific $\mathrm{IgE}$ and IgG antibodies in a patient sensitized to ethylene oxide through dialysis. J Allergy Clin Immunol 1988;82:679-86.

49. Mapp CE, Boschetto P, Dal Vecchio L, Fabbri LM. Occupational asthma due to isucyanates. Eur Respir J 1988; $1: 273-9$.

50. Borm PJA, Bast A, Zuiderveld OP. In vitro effect of toluene diisocyanate on beta adrenergic and muscarinic receptor function in lung tissue of the rat. $\mathrm{Br} \mathrm{J}$ Ind Med
1989;46:56-9.

51. Musk AW, Peters JM, Wegman DH. Isocyanates and respiratory disease: current status. Am J Ind Med 1988;13:331-49.

52. Tse CST, Pesce AJ. Chemical characterization of isocyanate-protein conjugates. Toxicol Appl Pharmacol 1979;51:39-46

53. Pepys J. Autoantibodies induced by extrinsic, low molecular-weight chemical allergens. In: Reed CE, ed. Proceedings of the XII international congress of allergology and clinical immunology, Washington, DC, St Louis, MO: CV Mosby Company, 1986:204-7.

54. Evans JC, Jackson SK, Rowlands CC, Baratt MD. Covalent binding of human serum albumin and ovalbumin by chloramine-T and chemical modification of the proteins. Anal Chim Acta 1986;186:319-23.

55. Lemke HD, König L. Allergy to ethylene oxide (ETO) and to muscle relaxants is mediated by cross-reacting IgE against quartenary ammonium ion determinants. In: The American Academy of Allergy and Immunology. Forty-forth annual meeting, March 11-16, 1988, Anaheim, CA. Anaheim, CA: The American Academy of Allergy and Immunology, 1988:269.

56. Barnett RN. Clinical laboratory statistics. 2nd ed. Boston, MA: Little, Brown and Company, 1979:105.

57. Byfield PGH, Copping S, Himsworth RL. Subfraction of human immunoglobulin $\mathrm{G}$ with dye-Sepharose adsorbents. Mol Immunol 1984;21:647-52.

58. Birkenmeier G, Tschechonien B, Kopperschläger G. Affinity chromatography and affinity partitition of human serum pre-albumin using immobilized Remazol Yellow GGL: evidence that albumin increases binding of prealbumin to the dye. FEBS Lett 1984;174:162-6.

59. Kopperschläger G, Birkenmeier G. Affinity partitioning: a new approach for studying dye-protein interactions. J Chromatogr 1986;376:141-8.

60. Mirgel V, Nachtkamp K. Chemische Aspekte vernetzender Einbrennurethanharze. Farbe Lack 1983;89: 928-34.

61. Markham TN, Fishburn CW. Sensitivity to toluene diisocyanate in an adhesive. J Occup Med 1967;9:471-3.

62. Samokhin GP, Filimonov IN. Coupling of peptides to protein carriers by mixed anhydride procedure. Anal Biochem 1985;145:311-4.

63. Paik CH, Murphy PR, Eckelman WC, Volkert VA, Reba RC. Optimization of the DTPA mixed-anhydride reaction with antibodies at low concentration. $\mathrm{J}$ Nucl Med 1983;24:932-6.

Received for publication: 3 July 1989 